\title{
Warsztaty twórczego pisania jako zadanie retoryczne...
}

Katarzyna Czarnecka 
nAPNS Seria IX 2003

\section{Katarzyna Czarnecka}

\section{Warsztaty twórczego pisania jako zadanie retoryczne}

$\mathrm{K}$

lasycznie rozumiana retoryka bywa definiowana jako sztuka przemawiania, teoria i sztuka wymowy ${ }^{\prime}$, teoretyczna i praktyczna nauka sprawnego mówienia ${ }^{2}$, przygotowująca do wystąpień publicznych - i w takim ujęciu wiąże się z komunikacją ustną, ze słowem mówionym. Potwierdza to jeden z poglądów przytaczanych przez Jerzego Ziomka:

Retoryka jest sztuką wymowy, czyli slowa wyglaszanego, i w tym sensie jest komplementarna wobec sztuki pisarskiej ${ }^{3}$.

Dzięki późniejszym reinterpretacjom możliwe jest szersze traktowanie retoryki, objęcie jej zakresem nie tylko tekstów wygłaszanych bądź przynajmmiej przeznaczonych do ustnej prezentacji, ale i wszelkich wypowiedzi pisemnych (w dalszej konsekwencji takze innych tekstów kultury, na przykład obrazu filmowego czy przekazu reklamy). Literatura przedniotu obfituje w takie sformulowania jak, ,retoryka jako teoria (...) konstrukcji tekstów” czy „retoryka tekstu pisanego" ". Zachęcają one do oglądı każdego tekstu w kategoriach retorycznych, to znaczy do odszukania elementów typowych dla sztuki retorycznej tak w samym procesie powstawania tekstu, jak i w kształcie skoníczonego dzieła. Podobne operacje mogą dotyczyć zarówno wypowiedzi spontanicznych, jak i wywołanych przez zaplanowane działania, także o charakterze dydaktycznym. I) la potrzeb niniejszego szkicu pragnı̨̨ zaproponować wykorzystanie narzędzi retorycznych do opisu niektórych aspektów warsztatów twórczego pi-

' Zob. M. Glowiński, T. Kostkicwiczowa. A. Okopicń-Shawińska. J. Slawiński. Ston'nik terminún' liternckich. Wroclaw 1988, s. +32 .

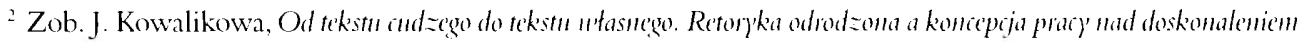

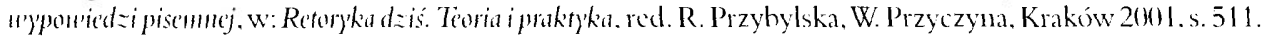

'J. Zionek. Retoryka opison'a. Wrochaw 1990), s. 15.

${ }^{+}$J. Z. Lichański, Nancanic retoryki. Problemy' metodyczme, w: Retoryka dzis. op. cit., s. 486.

J. Kowalikowa. op. cit., s. 511. 
sania, będących częścią edukacji studentów polonistyki Uniwersytetu Adama Mickiewicza, którzy wybierają specjalność dziennnikarską.

Zajęcia poświęcone twórczemu pisaniu odbywają się na V roku i obejmują 30 godzin, czyli 15 spotkań; ich uczestnicy mają więc za sobą prawie wszystkie przedmioty filologiczne, w tym caty kurs historii literatury polskiej (wyjąwszy przegląd najnowszych zjawisk), zagadnienia językoznawcze i teoretycznoliterackie oraz większość zajęć składających się na program specjalności dziennikarskiej. W ciągu czterech lat stıdiów wymagano od nich redagowania kilku rodzajów tekstów; przede wszystkim byly to utrzymane w stylu naukowym referaty, zbliżające się niekiedy do poetyki eseju (rozprawki opatrzone aparatem bibliograficznym, udowadniające pewną tezę, analizujące zjawiska literackie, językowe, kulturowe itp.), a także omówienia, sprawozdania, ewentualnie recenzje i konspekty. Program specjalności wyraźnie wzbogaca doświadczenia: adepci dziennikarstwa przechodzą przez roczne kursy stylistyki i retoryki, zdobywają umiejętności związane z pisaniem rozmaitych tekstów użytkowych, poshugiwaniem się wszystkimi stylami funkcjonalnymi, uczą się przygotowywać na piśmie, a także improwizować obszerne wystąpienia ustne. Gruntownie poznają również specyfikę tekstı dziennikarskiego, począwszy od jego elementów składowych po samodzielne redagowanie prac spełniających wymogi kilkunastu gatunków dziennikarskich. Osoby biorące udzial w obowiązkowych warsztatach twórczego pisania zostaja jednak postawione w nowej sytuacji komunikacyjnej. Muszą zerwać z żywym wciąż, niestety, wzorcem minimalisty, ograniczającego się do przyswajania podanych treści i ewentualnej dyskusji z poglądami odnajdywanymi na kartach literatury, przestają być wreszcie - jak sami zauważają w trakcie kursu - tylko odbiorcami czy sprawozdawcami napisanych przez kogoś innego tekstów lub metatekstów. Wykraczają równiezz poza tradycyjnie rozumiany obszar aktywności dziennikarza, będącego autorem wypowiedzi o charakterze informacyjnym albo publicystycznym; wewnętrzna umowa wyraźnic zaleca unikanie podobnych form wypowiedzi. Filologowie, przygotowywani podczas kilkuletniego programu zajęć z historii i teorii literatury raczej do zadań profesjonahnego analityka i interpretatora, przyjmują teraz rolę twórcy tekstów o charakterze literackim (a przynajmniej paraliterackim). Zmienia się zatem perspektywa: z osób spotykających się z gotowym utworem przeobrażają się w autorów, zapraszanych do napisania (i to w czasie ograniczonym do tygodnia lub dwóch) tekstu związanego ze wskazanym problemem, niekiedy też - do uwzględnienia pewnych rygorów formalnych. Rozbudzając możliwości twórcze, ćwiczenia dają szansę rozwoju takich predyspozycji, jak zdolność obserwacji i kojarzenia, wrażliwość na realia wspólczesności. W pewnej mierze nawiązują do starożytnych wyobrażeń o rzemiośle słowa - stanowią uwspólcześnioną wersję progymnasmatów (preexercitamentów)", czyli ćwiczeń przygotowawczych, doskonalących współbrzmienie myśli i mowy. Pozwalają również odwołać się do antycznej teorii procesu retorycznego przekonywania, zwłaszcza zaś do tych wymiarów perswazji, które określa się terminami movere i delectare; redagowane przez studentów teksty o charakterze literackim nie muszą bowiem in- 
formować czy pouczać (docere), z cała pewnością wszakże mogą wywolywać skutki w sferze woli (poruszyć, wzruszyć, nakłonić) lub uczuć (funkcja estetyczna). W tym miejscu warto przywolać zdanie Barbary Bogolębskiej, zastanawiającej się nad pozycją retoryki w dydaktyce szkolnej:

Retoryka jako zbiór technik tworzenia tekstı ksztalci możliwości kreacyjue uczniów, w tym sensie jest nauką pisania, efektywnego posługiwania siç słowem niezależnie od tego, czy tekst nawiązuje do jakiegoś zdarzenia czy innego tekstur?.

Idąc tym tropem, można postawić tezę, że uniwersyteckie warsztaty twórczego pisania są zadaniem retorycznym lub — dokladnicj — cyklem takich zadań.

Teksty, powstające w ramach omawianych zajęć, powinny wiązać się z podanym wcześniej zagadnieniem. Może to być obraz (na przykład niezwykla fotografia), cytat, rekwizyt, temat, motyw i tym podobne ${ }^{\aleph}$. Od pomysłowości studentów zależy, w jaki sposób dwoje z nich poprowadzi czterdziestopięciominutową część ćwiczeń, dotyczącą danego problemu. Jej zakończeniem jest sprecyzowanie zadania (narzucone przez prowadzącego lub będące wynikiem wspólnych ustaleni), które nie musi wynikać bezpośrednio z treści odbytych zajęć. Odtąd — dla każdego z uczestników z osobna - zaczyna się wlaściwy proces tworzenia tekstu, a więc procedura retoryczna.

Zgodnie z pięcioczęściowym schematem perypatetyckim, przedstawiającym etapy retorycznego postępowania, praca nad przygotowaniem wypowiedzi rozpoczyna się od inw e n c j i - gromadzenia danych, wynajdywania myśli, wyszukiwania sposobów rozwiązania postawionego problemu". Wszyscy nczestnicy warsztatów opracowıją w danym tygodniu to samo zagadnienie, które nie zależy od ich wyboru; odpowiada to zapisywanym w podręcznikach spostrzeżeniom dotyczącym klasycznych regul inwencji (np. „Mówca nie wymyślał więc tematów (...); temat był najczęściej «dany» przez saną przyczynę, która skłaniala mówcę do opracowania i wygłoszenia mowy"10). Wskazane tematy bywają przyjmowane ze zdumieniem (na przyklad: „Napisz tekst, w którym istotną rolę odgrywać będą buty”), nie zawsze jednak wyróżniają się bezwzględną nowością: jak pisze o ćwiczeniach retorycznych Barbara Bogolębska:

...temat nie musiał być oryginalny, cechą taką natomiast powinien odznaczać się sposób ujęcial!.

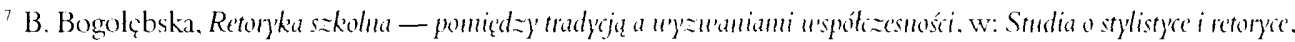
Zgicrz 2001, s. 251.

* Obszcrny zasób takich propozycji zawicra książka Izabcli Filipiak Tirércze pisanne dla mtody'ch panien. Warszawa 1999.

${ }^{4}$ Por. M. Korolko, op. cit.. s. 57-58.

"I) Ibidem.

"B. Bogolębska. op. cit., s. $2+5$.
} 
Oryginalność ta - jak się okazıje - jest potężnym wyzwaniem. Podstawowa trudność wiąże się z nieznośnym dla wielu osób uczuciem déjà lı - a zatem z ryzykiem powtarzalności ujęć i motywów literackich. Dotyczy to zarówno prób poetyckich (dodajmy, że powstawaly one niezwykle rzadko), jak i prozatorskich, stanowiących ponad 90 procent wszystkich prac. Jako przykład przytoczmy urywki wiersza, w którym pojawiają się wyeksploatowane już obrazy, kojarzące marzenie z blękitem i zankiem (na lodzie): ,i tak otwarłam/kluczem marzeń/ mój blękitny zamek" "2, deszcz zaś - z płaczem: „załzawione okna kamienic”. Twórcy malych form prozatorskich chętnie sięgają na przyklad po motywy mitologiczne, tworząc od nowa perypetie znanych postaci. Autorka opowieści o zrozpaczonej Penelopie, lekceważonej przez męża, lokuje akcję w scenerii starożytnej (praca miała wiązać się z cytatem „Posiadanie uczuć to przeciez jest ryzyko"'.3); kto inny posługuje się bohaterami mitologicznymi (Ariadną, Tezeuszem i Minotaurem), by zrealizować wymóg prezentacji problemu z trzech punktów widzenia. Zabiegi obecne w studenckich utworach powtarzają wzorce znane z kart wielkiej literatury; na przykład rzymskich bogów przenosi się w realia wspólczesne — tak skonstruowana została historia I Jermesa, który opowiada o sobie pewnemu Amerykaninowi:

Już od dawna podróżuję incognito — autostopem, pociągiem — żeby nie wzbudzić jakichkolwiek podejrzeń. Jak sam widzisz, pozwala mi to spotęgować efekt zaskoczenia. Nikt nie spodziewa się starego Hermesa, który utknął w polı z powodu śnieżycy czy strajku kolejarzy.

Bardziej oryginalne byly prace oparte na motywach historycznych, takich jak samobójstwo hrabiego Edwarda Raczyńskiego czy małżeństwo wielkiego księcia rosyjskiego Konstantego, lub odwołujące się do nazwisk spopularyzowanych przez kulturę masową (Józef Tkaczuk - bohater graffiti). Jak zauważają sami studenci, prawie każde pojawiające się w ich „dziełkach” wydarzenie zdaje się mieć swój mniej lub bardziej oczywisty pierwowzór, kojarzy się z doświadczeniem czytelniczym, sceną z filmu, stereotypem kultury. Wobec groźnego przypuszczenia, które sprowadza się do konstatacji „.wszystko (bądź prawie wszystko) już było", pozostaje szukać przestrzeni jeszcze nie wyeksploatowanych (o ile takie istnieją — dodawali sceptycy).

Rozważając kwestię wtórności tekstów, wspomniana już Barbara Bogołębska zauważa:

...oryginalny, niekonwencjonalny temat z czasem zamienil się w topos powtarzany intertekstualnie. Jeduak nadużywany stawał się banalem, kliszą myślową, stereotypem, a nawet parodią ${ }^{1+}$.

Podobne spostrzeżenie bardzo wcześnie zrodzito się wśród uczestników warsztatów jako konsekwencja pierwszych prób realizacji twórczych zadań. Filolog zabierający się do pisania

12 Cytowanc fragmenty pochodzą z prac studenckich, zlożonych $w$ roku akademickim 2001/2002.

12 I. Filipiak. op. cit., s. $1+0$.

${ }^{1+}$ B. Bogolębskik, op. cit.. s. 247. Klasyczna retoryka mieści toposy w obszarze inwencji, por. M. Korolko, op. cit., s. of i nastçpne. 
chętnie zredagowałby formy wtórne, stylizowane: pastisz, parodię lub trawestację. Potrafi bowiem wydobyć istotne cechy planu formy i treści, wpisać się w konwencję sentymentalnego romansu lub opowieści kryminalnej graniczącej z horrorem, a przynajmniej wie, skąd zapożyczyć wątki lub koncepcję relacji międzyosobowych (co czyni zresztą niekoniecznie świadomie). Kolejna trudnością w obszarze inwencji - poszukiwania pomysłów okazalo się przezwyciężenie skłonności publicystycznych, wiodących aż do przykładów literatury tendencyjnej. Zadanie „Czego dziś nie widziałem” przyniosto na przyklad bardzo interesującą wypowiedź o lęku przed utratą tożsamości, spowodowanym faktem niespojrzenia w lustro („nie widziałam dziś rano swojej twarzy..." ${ }^{15}$ ), ale i dydaktyczny, nieatrakcyjny tekst o niedostatku dżentelmenów ustępujących miejsca w tramwaju:

...z żalem stwierdzam, że nie widziatam dziś gentlemana ustępującego miejsca kobiecie spodziewającej się dziecka. (...) Zarzućmy więc zaczepny feminizm i doceńmy szarmancję.

Zdarzały się także rozwiązania, które czytelnicy zgodnie uznali za zbyt erudycyjne. Nadmierna oryginalność staje się wówczas przeszkodą w odbiorze tekstu - jak choćby w przypadku opowiadania o tytule Ketman 2; tajemnicze zjawisko określane słowem ketman, obecnym w niektórych tylko slownikach wyrazów obcych ${ }^{16}$, było również podstawą do zrozumienia calej wypowiedzi. W toku rozmów pojawiło się interesujące pytanie o ewentualne granice oryginalności i wymagań stawianych odbiorcy. Udzial w kursie twórczego pisania pozwolil przynajmniej na uświadomienie sobie niektórych pułapek, związanych z obszarem retorycznej inwencji, która — zdaniem Jerzego Ziomka — nie opiera się na uzdolnieniach i wrodzonej pomysłowości, lecz jest „szkoloną umicjętnością"17.

Drugim z kolei etapem retorycznego postępowania jest d y s p o z y c j a, czyli uporządkowanie „wynalezionych dzięki inwencji elementów mowy”" Teksty powstające w związkı z zajęciami przyjmowały najczęścicj — zwykle z wyboru autorów — postać prozy, zwłaszcza fabularnej. Doświadczenia pisarskie, a także krytykowane nieporadności ulatwily zwerbalizowanie kilku pozonic oczywistych zasad warsztatowych. Jak się okazuje, nawet bardzo oczytane osoby nie zawsze zdają sobie sprawę z tego, że rekwizyt (zwłaszcza charakterystyczny, niezwykly) wprowadzony do narracji nie powinien być tylko elementem dekoracyjnyn. Innymi slowy, nie warto lekceważyć starej prawdy: pistolet pojawiający się na początku wi-

\footnotetext{
${ }_{15}$ Początck opowiadania: „Nic widzialann dziś rano swojcj twarzy. Tak po prostu. Wstalan zbyt późno, a potem. ciągle myśląc o mającym zaraz odjechaćautubusic, mylam siç, nic patrząc w lustro. Na autobus zdążlam, chociaz whaściwic. sicdząc w środku na niewygodnym fotclu. zaczçłaun w to wątpić. Wszystko z jednego powodu - nie widziałam rano swojcj twarzy. Wystarczyło sobic to uświadomić, a w glowie zaraz zrodziło siç pytanic: "czy ja to ja?». Przeciezz wlaśnic twarz jest tą częścią ciala. po której jesteśny rozpoznawahni”.

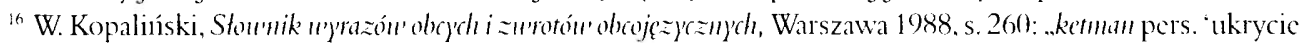
się, zamaskowanic', w islamic - zwolnicnic od trzymania sic̨ przepisów religijnych w sytuacji przymusu albo zagrożcnia, dozwalające w krańcowych przypadkach na pozorne wyparcie się wiary". Wyrazu ketman brak

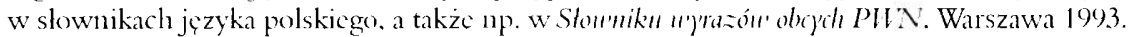

1" J. Ziomek, op. cit., s. 78.

${ }^{10}$ M. Korolko, op. cit., s. 82.
} 
nien wystrzelić chociażby w ostatniej scenie. Potrzebę takiej reguly potwierdzil pewien eksperyment. przeprowadzony na prośbę studentów. Zgodnie z ich propozycja, jedno spotkanie zostało poświęcone na próbę wspólnego, zespołowego zredagowania opowiastki, będącej rozwinięciem uzgodnionego obrazu. Ponysł byl groteskowy, nieco makabryczny: ktoś przechodzi parkową alejką i dostrzega wystającą spod stosu zgrabionych liści ludzką rękę z przedziwnym pierścieniem na palcu. Jak się okazało, największym kłopotem w budowaniu fabuły bylo sensowne wkomponowanie fragmentów, thumaczących istnienie owego klejnotu. Trudności przysparzalo wielu osobom także przekonujące rozwiązanie zbudowanych wcześniej konfliktów lıb zakończenie akcji; wstępna idea, określona na etapie inwencji, wymaga doprecyzowania, zamknięcia, a ostatnie linie tekstu mogą decydować o sukcesie lub porażce autora $^{19}$. Niektórzy uczestnicy zajęć zdradzali swą bezradność, znienacka uśmiercając niewygodne postaci lub wysyłając je, bez uzasadnienia, w nietypowe miejsca (na przykład na „bezpańskie wrzosowiska”). Wyjątkowo rażące było nadużywanie aktualiów - po ataku na Nowy Jork dzialalność terrorystów mogla być przyczyną lub skutkiem każdego zwrotu akcji, najczęściej zaś służyła do zamknięcia opowieści o malej sile perswazji; w pracach zawierających ten motyw trudno dopatrywać się zabiegów ironicznych czy świadomego przerysowania ${ }^{21}$.

Zadania, akcentujące problemy kompozycyjne, mogą polegać na obowiązku wprowadzenia do tekstu określonych form podawczych, na przykład samodzielnie napisanego dialogu (w mowie niezależnej) lub gotowego listu, którego formy i treści nie wolno zmieniać. Ostatnie z wymienionych ćwiczeń przyniosło naprawdę ciekawe prace. Studentom wręczono kartki z tekstem piętnastowersowego, autentycznego listu, z którego usunięto jedynie dane umożliwiające identyfikację nadawcy i czasu (datę, podpis, nazwę miejscową). List ten, pisany w rzeczywistości przez Edytę Stein do Romana Ingardena, przyszli dziemnikarze wkomponowali na przykład w opowiadania o żonach: porzucającej męża lub pragnącej wywołać jego zazdrość, o Naparstku - podróżniku zakochanym w Maszynie do Szycia, o matce zastanawiającej się po śmierci córki nad tym, czy jej narzeczony zdążył otrzymać ów list. Udane byly też próby zredagowania formy epistolarnej — wymiany korespondencji między romantycznymi kochankami oraz między hitlerowskim oficerem, zachwyconym architekturą miasta Danzig zdobywcą Poczty Gdańskiej a młodą Niemką poznaną w głębi Rzeszy tuż przed wybuchem wojny.

Ostatnią częścią retoryki mającą bezpośredni związek z tworzeniem tekstu, którego nie przeznaczono do wygłoszenia, jest e lo k u c j a, sztuka wysłowienia „zajmująca się celowym i stosownym do myśli użyciem słów" "21. Wykreowany świat domaga się bowiem kształtu języ-

\footnotetext{
${ }^{14}$ Przypomnijmy, że „teoretycy retoryki przykladali do stosownej konstrukcji zakończenia bodaj najwiçksze znaczenic, ponicważ decyduje ono o ostatecznynn celu przekonywania i umicjętnościach mówcy" - M. Korolko. op. cit., s. 99.

2" Wyjątek stanowi zartobliwe opowiadanic o tajemniczych znakach wycinanych w lanach zbóz. Ostatnie zdanic brzmi następująco: .. Osama bin Laden juz w latach osiemdziesiątych pobral próbki polskiego zboża do celów bioterroryzmu".

"M. Korolko, op. cit., s. 102.
} 
kowego. Uczestnicy zajęć przekonywali się w praktyce, jak bardzo znaczący jest wybór każdego określenia. Slowa, zapisywane początkowo dosyć automatycznie, nawet bezmyślnie, odzyskiwaly swoją wagę po kilku tygodniach ćwiczeń, gdy autorzy uwrażliwiali się wzajemnie, podważając zasadność nżycia nicktórych sformulowań. Studenci borykali się częstokroć z problemani stylistycznymi: poszukując ekwiwalentu zużytych metafor i pustych epitetów, zmagali się z manierycznością i nie zawsze udanymi poetyzmami. Dostrzegalny był trud odnajdywania formul, pozwalających opisać rzeczywistość: „pytanic zgasło”, „wróble próbują swoich sił wokalnych”, „ranek wygrywa swą szarą melodię turkotem tramwajów”. Dążenie do oryginalności ujęcia przynosiło niekiedy zapisy wyjątkowo kuriozalne, na przykład „Dziecko jest niby nowiuteńka siekierka - gotowe rąbać życiowe drwa bez wytchnienia”. Dla unaocznienia skali problemu przytoczmy krytykowane tytuly prac: Depresja rózou'ych lakierkón' albo enforia ziclonych kalosz;; Znien'olone bogactu'o uczuć oraz fragmenty tekstów uznane za chybione:

Posępne obrazy i stowa jak male, rodzące się wolno potwory wynurzały się z rozkutego pancerza nieświadomości;

Magda zaczęla dojrzewać. Na jej twarzy rozmmożyly siç małe wulkany;

Pojawia się rozum, który swomi brudnymi buciorani depta po instynktach;

W szranki ze zmyslami staje sumienie, którego przeraźliwy z reguły pisk zaghusza wszelkie popędy czy chęci;

Przestrzenie życia inkrustowanego amerykańską art tandetą, a jednocześnie przesyconego lucyferycznością.

Niektóre z powyższych urywków miały zapewne wyróżniać się obrazowością lub ozdobnością, wykraczają jednak przeciw podstawowym zaletom wysłowienia, uwydatnianym przez teorię retoryki: przeciw jasności i stosowności. Chęć uplastycznienia tekstu doprowadza do popadnięcia w pretensjonalne schematy, które uwidaczniają się w powtarzaniu pewnych zestawień, np. jeśli „trawa”, to „soczyście zielonia”, jeśli „brzozy”, to „srebrzyste”, jeśli „róże”, to na pewno „pąsowe” lub „szkarłatne”, jeśli „., spadł śnieg”, to „rozlewa się ocean śnieżnej bieli". Największe niebezpieczeństwo kiczu kryje się w opisach przyrody oraz w przedstawianiu sytuacji nacechowanych pozytywnymi emocjami, na przyklad czulością wobec niemowlęcia (z pracy pod tytutem: Zapach zótciutkiego kurczątka):

Jesteśmy w pokoiku Zuzi. Rozpoczął się nowy rozdział w naszym wspólnym życiı. Jej uśmiech jest jak złocisty promień słońca w mroźny dzień; jej rączki jak najdelikatniejszy platek róży; i ten zapach, który nieodlącznie towarzyszy maleństwu - zapach wielkanocnego, puchowego kurczęcia - to dziwi być może, ale od kiedy paniętan, tak mi się kojarzył zapach niemowlęcia. Moja córeczka ma cudowne oczy, jak dwa paciorki, przysłonięte woalką rzęs ${ }^{22}$.

\footnotetext{
2 Na prawach kontrastu nalezaloby przytoczyć zdanic: .Jego czerwonc cialko wychlusnçlo w ręce polożucj o godzinic dwrimastcj".
} 
Próby poetyckie grożą popadnięciem w ewidentną grafomanię:

Nie widziałam malej polanki,

którą z bajek znałam,

obiecanej niespodzianki,

na którą czekalam.

Morskich fal i piasku,

stonecznego blasku,

mew, albatrosów

i polnych klosów.

Względy językowe, a dokładniej: niemożność wyzwolenia się z utrwalonych stereotypów i odpowiadających im połączeń wyrazowych, przesądziły też o niepowodzeniu zadania, podjętego na wyraźne życzenie studentów - nie udało się napisanie ciekawych kolęd. Dla dopelnienia obrazu należy jednak odnotować także sukcesy: osoby o dużych zdolnościach i sprawnym warsztacie świetnie radzą sobie z dynamiką tekstu, osiąganą na przykład dzięki odpowiedniej sktadni. zgrabnie redagıja sugestywne stylizacje, odpowiedzialnie ważą każde słowo. Największym uznaniem grupy cieszyly się prace nie tylko pomysłowe w zakresie in'entio, ale i interesujące pod względem językowym: pozbawione udziwnień, budzące wręcz szacunek brakiem jakiegokolwiek zbędnego wyrazı, trafnością ujęcia, bogactwem leksyki.

Innym problemem, lokowanym w obrębie elokucji, jest kwestia poprawności językowej (latinitas) - ujmując rzecz skrótowo, poprzestańmy na stwierdzeniu, że w tekstach studentów V roku niewiele jest usterek ortograficznych i gramatycznych; więcej klopotu sprawia interpunkcja; największe zaś trudności dotyczą plaszczyzny leksykalnej, semantycznej (po części: logicznej, na przyklad ..kruchy jak puszek”) i stylistycznej, czego dowodziły przytaczane wyżej cytaty. Trzeba podkreślić, że wspomnianych niepowodzeń w sferze poprawnościowej nic można traktować jako efektu celowych zabaw językowych; uczestnicy ćwiczeń najwyraźniej tęsknili do klarownej prozy, nie podejmowali, o dziwo, śmielszych eksperymentów, porównywalnych do dadaistycznego wyciągania słów z kapelusza.

Etap elokucji zanyka pracę nad powstawaniem tekstu pisanego ${ }^{23}$, nie kończy jednak dzialań prowadzonych w ramach zajęć twórczego pisania. Obowiązkiem każdego z członków grupy jest bowiem zapoznanie się z efektami wysilków wszystkich kolegów; umożliwia to późniejszą rozmowę o sposobach realizacji kolejnych zadań. Rozmowy takie, niekiedy przeradzające się w zaciekłe dyskusje o charakterze krytycznoliterackim lub filozoficznym² ${ }^{24}$, są świadectwem recepcji tekstu, a jako takie moglyby również podlegać analizie retorycznej.Jak podkreśla Jerzy Zionnek, retoryka jest

\footnotetext{
${ }^{3}$ Pomijamy zatem sztukę zapanniçtywania tekstu przeznaczonego do ustncj prezentacji oraz samo wygloszenic - actio, obejmujące caloksztalt dzialań werbalnych i pozawerbahych. skladających się na wystapienie retoryczile.

I+ Szczególnic kontrowersyjue problemy to: sposób wartościowania, możliwości oceny tekstu o charakterze literackim (nieużytkowym). granice sztuki i grafonania. ukryty autobiografizm itp.
} 
...zarówno sztuką wytwarzania, jak i odbioru tekstów, i nie ma potrzeby dla opisu kultury „czytania” powolywać innej nazwy ${ }^{25}$.

Takie ujęcie pozwala zatem pomieścić w obrębie retoryki użytkowej caloksztalt przedsiçwzięć, podejmowanych podczas przeznaczonych dla przyszlych dziennikarzy zajẹć twórczego pisania.

.5. Jionek, op. cit., s. 16. 